\title{
Ceremonias letradas: representaciones del campo cultural en la narrativa de autoras latinoamericanas y caribeñas de la primera mitad del siglo $X^{1}{ }^{1}$
}

Literate Ceremonies: Cultural Field's Representations in Narratives by Latinamerican and Caribbean Women Writers (First Half of the 20th Century)

\author{
Natalia Cisterna Jara \\ Universidad de Chile \\ nataliacisterna@u.uchile.cl
}

Este artículo tiene como fin analizar las representaciones del campo cultural en las
narraciones de un conjunto de escritoras latinoamericanas y caribeñas de la primera
mitad del siglo XX. A pesar de que en ese contexto los cambios modernos en los campos
culturales impactaron en su quehacer literario e intelectual, las escritoras mayorita-
riamente eligieron no dar cuenta, de manera explícita en sus obras, de sus vivencias
en el seno de las esferas letradas. El artículo se centra en esta ausencia representa-
cional, observando que en ningún caso esta obedeció a un desinterés por parte de las
escritoras por pensar e imaginar su ejercicio profesional sino, por el contrario, fue una
forma particular de hablar de las dificultades y exclusiones que ellas experimentaron
en los campos culturales. El texto plantea que, frente a la ausencia de imágenes de
esferas culturales modernas, las narraciones despliegan una variedad de escenas de
lectura y actividad cultural, que llevan a cabo las protagonistas en espacios privados
e íntimos. El artículo analiza en estas imágenes ciertas características que disponen
un modelo de desarrollo e interacción cultural alternativo al existente en las esferas
letradas en las que ellas estaban inmersas.
Palabras clave: Literatura de autoras latinoamericanas y caribeñas, campos culturales.

The purpose of this article is to analyze the representation of the cultural field in the narratives of Caribbean and Latin American women writers during the first half of the 20 th century. Despite the modernization of the cultural field and its impact on their literary and intellectual endeavors, these women writers chose not to represent their experiences in the lettered spheres explicitly in their work. We view this representational absence not as disinterest in reflecting on and imagining their professional practice as writers, but rather as the particular way in which these women expressed the difficulties and exclusions they experienced in their contemporary cultural fields. We show how these narratives display a series of scenes in which the main characters engage in reading and cultural activities within private and intimate settings. By analyzing the particular characteristics of these images, we demonstrate how they offer an alternative model of development and cultural interaction to the existing lettered fields of their time. Fields.

Keywords: Latin American and Caribbean Women Writers Literature, Cultural

Recibido: $15 / 08 / 2015$

Aceptado: 04/10/2015

1 Este artículo se inscribe en el marco de los proyectos de investigación FONDECYT Iniciación: No 11121340 "Ficcionalizar y pensar la cultura: Análisis a las reflexiones sobre los campos culturales y modelos literarios en la narrativa de autoras latinoamericanas de la primera mitad del siglo XX" y Fondecyt Regular: No 1140745 "Constitución de autorías femeninas en el campo literario del Caribe Hispánico: 1830 a 1945" Investigadora responsable, Lucía Stecher. 
"Lo único que considero bien escrito en Ifigenia es lo que no está escrito. Lo que tracé sin palabras" (Teresa de la Parra, 1926)

"¿Qué es en efecto este discurso que habla sobre el mundo (social o psicológico) como si no hablará de él; que solo puede hablar de este mundo con la condición de hablar de él como si no hablara de él [...]?" (Pierre Bourdieu, Las reglas del arte)

\section{Decir sin decir: hablar de la cultura desde lo privado}

En el cuento "Niú" (1926) ${ }^{2}$ de Marta Brunet, el personaje Marcial Moreno, escritor y crítico, le cuenta a un amigo los acontecimientos que lo llevaron a una vida desgraciada, después de haber disfrutado del reconocimiento en el mundo intelectual. La causa de su desventura es una mujer, una joven poeta llamada Niú. Antes de conocerla personalmente, el escritor la había convertido en el blanco de algunas ácidas columnas críticas. Para el letrado, la obra poética de Niú se limitaba a reproducir los lugares comunes de la literatura erótica y evidenciaba un trabajo literario descuidado. En medio de esta polémica, Niú le envía al crítico una invitación a su casa. Sin razón alguna este decide asistir. La mujer lo recibe vestida con una túnica y rodeada de una ambientación orientalista. Sin decir una palabra, la poeta se le acerca y lo besa. El escritor, completamente paralizado, se rinde ante ella. La poeta se aleja, lo mira con sarcasmo y le dice, parafraseando una de las tantas líneas que escribió en su contra, "-Caso patológico. Poema breve. ¿Le ha agradado al señor crítico la página que acabo de escribir?" (34). Es el inicio de la caída. El escritor, seducido y desechado, se transforma en un ser fantasmal, una figura patética que terminará acechando a la mujer y rogándole por un nuevo encuentro.

El relato de Brunet es una pieza interesante para los que nos dedicamos a estudiar la literatura desde una perspectiva de género. Son muchos los elementos que aquí se ofrecen de forma evidente que permiten ahondar en los modos cómo el sujeto femenino se ha construido en la tradición cultural y, especialmente, literaria. Sin embargo, lo que llama particularmente mi atención en este relato no es lo que aparece de manera más o menos clara, sino lo que no está visible, aquello que Brunet elige omitir. Me refiero a la dimensión material y social del campo cultural y, junto con ello, las condiciones concretas del trabajo literario e intelectual que enfrentaron las escritoras de las primeras décadas del siglo XX. Nada es más distante a las tomas de posición de las autoras dentro del campo cultural de aquellos años, que una femme fatal extravagante, ajena a las dificultades materiales de su contexto ${ }^{3}$ y abiertamente insolente con las críticas del mundo letrado.

2 El relato se publica por primera vez en 1926 en la revista Atenea. Sin embargo, alcanza mayor difusión cuando se incluye en el libro de cuentos Reloj de sol (1930). La versión del cuento que utilizaremos en este artículo corresponde a este libro de relatos presente en sus Obras completas, editadas por Zig-Zag, en 1963.

3 En parte de su epistolario, Brunet dedica varios pasajes a describir las dificultades económicas que debía enfrentar: los gastos y ahorros obligada a hacer cada mes, como también las desagradables negociaciones con los editores para fijar el precio de sus relatos. 
Es evidente que el relato de Brunet no busca caracterizar a la protagonista y a su entorno de acuerdo con un marco histórico preciso. Las dos apariciones de la poeta tienen lugar en medio de cronotopos indefinidos. Niú, al inicio del cuento, irrumpe en un espacio abierto, desdibujado por una espesa niebla. Su figura es lo único que se distingue en medio de la bruma que borra cualquier referencia de lugar. En tanto, la casa en el que se dan cita los personajes se describe como un ámbito extravagante y arquitectónicamente confuso, presidido por una Niú ataviada en total sintonía con el exotismo de su entorno: "[...] la encontré en el orientalismo de una casa absurda, llena de pasillos, de recovecos, de misterios, de medias luces. Ella misma, vestida con una túnica negra recamada de oro en dibujos chinos, era un ídolo en su templo" (33).

Brunet construye una escena teatral, repleta de gestos melodramáticos, ambientaciones efectistas y decoraciones recargadas, en donde la cotidianidad de las escritoras asalariadas no tiene presencia alguna. Nada sabemos de Niú, ni de su pasado ni de su presente, si está exclusivamente dedicada al quehacer literario o está obligada a desarrollar otras actividades para sobrevivir, como lo hacían las escritoras por aquellos años. Incluso su nombre remite a una invención, un sonido, sin apellido, sin genealogía 4 . Es precisamente en este vacío de información biográfica, social y epocal, en donde se traza un horizonte de referencias exclusivamente culturales. En efecto, el cuento invita a ser leído de acuerdo con ciertas pautas estéticas reconocibes en la tradición literaria. La figura de la poeta y su cronotopo están articulados bajo la imaginería decadentista y modernista. Asimismo, la poeta responde a un modelo femenino ampliamente difundido en literatura: la femme fatal. Niú es la otra, la extraña que rechaza los roles asignados a su género, andrógina, autónoma, seductora, objeto de deseo pero también sujeto deseante que lleva a la fatalidad a los varones que establecen algún vínculo emocional con ella. Niú es la cristalización de un tipo literario que puede ser reconocido no solo por los lectores sino también, a nivel intradiegético, por su contrincante dentro de la esfera letrada: Marcial Moreno. Y en eso radica el éxito de la venganza de Niú. La joven poeta le muestra al escritor precisamente lo que él espera ver, una imagen femenina ajustada a los estereotipos de la tradición artística androcéntrica. El crítico, cuyo deseo se articula en estos lenguajes, lejos de ser capaz de desmontarlos, termina sucumbiendo a ellos, perdiéndose en un laberinto discursivo en el que la mujer es solo un reflejo de espejos, vaciada de toda historicidad (32).

Si bien en el cuento no hay intención de analizar la situación de la mujer en su campo cultural considerando particularidades históricas, sí observamos una posición autorial crítica a un mundo letrado que pone obstáculos para la legitimación de las escritoras. El letrado juzga y condena la obra de Niú,

La información contenida en las cartas evidencia las preocupaciones cotidianas de la escritora por su subsistencia económica. Las transcripciones de las cartas de Brunet fueron facilitadas por el investigador Osvaldo Carvajal, quien trabaja actualmente en este material.

4 Una colega y amiga, María Lucía Puppo, me hacía notar que el nombre de la poeta podía relacionarse a la pronunciación fonética del término inglés new. La poeta, en tal sentido, encarna a la creadora nueva en el campo cultural, en este caso, la advenediza que no tiene mayores redes ni influencias, y que tampoco puede mostrar una trayectoria que la legitime en ese espacio. 
reproduciendo varios convencionalismos respecto de la mujer, asumiendo que esta es incapaz de elaborar discursos simbólicos complejos. Para el crítico la poeta hace lo único que puede hacer en cuanto mujer: desplegar, sin rigor alguno, versos eróticos que evidencian una naturaleza femenina sensual e irreflexiva. Brunet no busca polemizar directamente con estos convencionalismos, con los que ella sin duda tuvo que lidiar, más bien escoge revelar sus consecuencias. Para ello los pone en escena, los hace funcionar en una pequeña pieza dramática en la que el crítico y, a su vez, lo que él representa (el campo cultural), acaban siendo paralizados y finalmente devorados por ese juego asfixiante de discursos simbólicos.

Me parece interesante la decisión que toma Brunet de hablar y problematizar ese espacio letrado $y$, en particular, abordar las dificultades que encuentran las mujeres para insertarse en el mismo, desde una representación que pone entre paréntesis la vida social e histórica de su propio contexto de producción. Es interesante por dos razones: porque en su extensa obra, este tipo de representación no se limita solo a este cuento y porque, además, está presente en varias narraciones de otras escritoras del periodo. Tanto en el resto de la obra de Brunet como en el de muchas autoras latinoamericanas y caribeñas de las primeras décadas del siglo XX, asistimos a una necesidad de ficcionalizar de manera oblicua el lugar de la mujer en el ámbito público y cultural, configurando mundos en los que no se visibilizan sus experiencias en los espacios ciudadanos y en los campos culturales, como tampoco las distintas estrategias que usaron para alcanzar reconocimiento en ellos.

En los años en los que se publica "Niú", asistimos a la profesionalización del trabajo literario, producto de la modernización de los campos culturales. Estos cambios impactarán en los modos cómo las escritoras entenderán y desarrollarán su labor y en la definición de sus autorías. Las escritoras profesionales, a diferencia de sus antecesoras, asumirán el ejercicio literario no como una actividad ocasional, sino como una labor que les demandará tiempo y las obligará a una mayor sistematicidad (Doll). De igual modo, la escritora profesional tendrá conciencia que el reconocimiento no solo estará sujeto a la calidad de su trabajo, sino a su instalación en el campo cultural, para lo que serán determinantes las estrategias de posicionamiento en este espacio y las relaciones que establezca con los agentes legitimadores del mismo. Así, a diferencia de sus pares varones, las mujeres en su mayoría no se integrarán a las esferas intelectuales y artísticas a partir de acciones rupturistas, desconociendo o bien polemizando con el trabajo de las figuras reconocidas del mundo letrado. Por el contrario, las escritoras conscientes de su condición de recién llegadas a un ámbito predominantemente masculino, y definido por los mismos prejuicios de género que pueblan el resto de los espacios públicos 5 , buscarán tempranamente los apoyos de críticos 0 autores consagrados o bien reconocidos del campo cultural (Fletcher).

\footnotetext{
5 Rubí Carreño, en su análisis al campo cultural chileno y los procesos de legitimación que debían experimentar las autoras, dará cuenta de un mundo letrado, conformado exclusivamente por varones, que observaba con distancia a estas recién llegadas, con las que no compartía los códigos que articulaban la escena culural, ni tampoco confiaba en sus reales capacidades para igresar a ella. "Una escena crítica: estereotipos e ideologías de
} 
A esta instalación feble de las escritoras hay que sumar las precarias condiciones del trabajo literario asalariado, que afectaba en general a los autores. Con públicos lectores que no alcanzaban a constituir un mercado significativo que permitiera la total autonomía del oficio letrado, los autores en su mayoría debieron ejercer otros trabajos para poder subsistir. Muchos se inclinaron por tareas que tenían una mayor demanda en el campo cultural, como lo era la docencia y el periodismo (Rama), o bien por cargos en la administración pública o, los que tenían mejores contactos, por el mundo diplomático. De esta realidad no estuvieron ajenas las escritoras. Profesionalizar su oficio, al igual que sus colegas masculinos, no se tradujo en ningún caso en que pudieran vivir del mismo. De este modo, para las escritoras profesionales de la primera mitad del siglo XX, ingresar al campo cultural no solo significó enfrentar los obstáculos asociados a los prejuicios hacia su género sexual, sino también hacerse cargo de las dificultades económicas que el mismo conllevaba.

Si en su contexto social las autoras que se incorporaban a la vida cultural aprendían a resistir, negociar y sobrevivir en espacios de producción simbólica que tradicionalmente limitaban la incorporación de las mujeres, parece a lo menos inusual que en la ficción las escritoras elaboraran cronotopos que no dialogaban con estas vivencias. Susana Zanetti advierte precisamente esta contradicción entre las tomas de posición de las escritoras y las mujeres en general en el ámbito público, y cómo eran representadas en la literatura de mujeres:

Aunque a lo largo del siglo XIX -sobre todo en su segunda mitad- $y$ en las primeras décadas del $X X$, contemos con testimonios suficientes de escritoras $y$ abunden las argumentaciones para acordar con la intervención de la mujer en la esfera pública a través de la escritura y de la creación literaria, sobre todo a medida que se van intensificando las discusiones sobre los derechos civiles y políticos femeninos, son casi inexistentes en las novelas de entresiglos en América Latina retratos [...] en los cuales la lectura alienta las aspiraciones literarias. Raramente se ficcionaliza a la lectora que deviene autora, o busca serlo, incluso si finalmente fracasa (331).

A partir de esta constatación, la pregunta que surge es por qué razón las autoras eligieron silenciar en sus obras una realidad que las afectaba y que marcaba la vida cotidiana de la mayoría de ellas. Francine Masiello propone leer este silencio como una manifestación literaria de la exclusión que todavía experimentaban los sujetos femeninos en el ámbito público:

[P]ara el huérfano de la novela mundonovista siempre existe la posibilidad de definirse mediante el trabajo; desde la juventud hasta la madurez, el mundo del trabajo ayuda

género en la recepción crítica de Marta Brunet y María Luisa Bombal". Anales de Literatura Chilena, 3 (2002): 43-51. 


\begin{abstract}
al héroe en busca de su identidad. Pero en las novelas de Teresa de la Parra, Norah Lange o María Luisa Bombal las mujeres quedan fuera del mundo del trabajo. Ellas están relegadas a la vida de la imaginación, en cuanto ellas mismas están excluidas de la productividad laboral. Aun cuando sean artistas o escritoras [...], el arte no ofrece a estas mujeres ninguna solución totalizante. Más aún, ellas no se consideran grandes artistas ni esperan de su producción artística ninguna recompensa pública. Es decir, su creatividad es asunto privado; escriben sin que nadie las lea, visualizan sin pintar (812).
\end{abstract}

Para Masiello los impedimentos que las escritoras encuentran en estas esferas se expresan en protagonistas que no observan la actividad pública, intelectual y artística como caminos factibles para su desarrollo. La literatura de mujeres replegaría, entonces, a lo privado lo que en lo público carecía de reconocimiento. En otras palabras, las escritoras en su mayoría privilegiaron hablar acerca de su compleja instalación en lo público y en el campo cultural desde imágenes que remitían a otros escenarios, ajenos a las esferas letradas. En la narrativa de mujeres, los personajes femeninos se presentan sumergidos en mundos rurales o en esferas privadas ajenas al movimiento de las ciudades. Rodeadas de una espesa y protectora vegetación o en la seguridad de los cuartos, las protagonistas se transforman en receptoras o productoras de bienes simbólicos e intelectuales. Si volvemos al ejemplo inicial del cuento de Brunet, veremos cómo Niú lleva finalmente a cabo su acto creativo más perfecto y eficaz, no en las páginas de los diarios ni en uno de sus poemarios, sino en la intimidad de su casa. El beso castrador tendrá como testigo solo a ambos personajes.

En relación con lo anterior, no puedo dejar de referirme al epígrafe de Pierre Bourdieu que está al inicio del artículo. A partir de su lectura de La educación sentimental de Flaubert, el sociólogo se plantea una pregunta retórica que le permite dar cuenta de las características del diálogo que establece la literatura con el contexto social, es decir, evidenciar la particularidad de un discurso que habla respecto de su mundo "como si no hablara de él" y que al mismo tiempo, no puede hacerlo de otra manera. En otras palabras, y siguiendo a Bourdieu, el discurso literario remite a su contexto de producción sin necesariamente exponer de modo explícito los problemas, debates y fenómenos sociales presentes en el espacio social en el que tiene lugar la escritura de la obra. Como señala Bourdieu, la literatura tiene la capacidad de "desvelar velando".

Pues bien, es precisamente esta cualidad de la literatura, de decir sin decir, la que a mi modo de ver gran parte de las escritoras latinoamericanas y caribeñas, de la primera mitad del siglo XX, exploraron con singular sutileza y sofisticación. Por ello creo que es necesario indagar más en las formas de representación de esos espacios culturales devenidos en gestos y acciones privadas. Masiello propone una lectura interesante cuando visibiliza esta suerte de silencio representacional como una estrategia de las escritoras para hacerse cargo de los mecanismos de exclusión que las afectaban. Sin embargo, la respuesta de Masiello abre nuevas interrogantes acerca de las 
formas cómo se materializaron, en el plano de lo privado o íntimo, estas representaciones de la actividad cultural. En tal sentido, tiene lógica preguntarse respecto de los tipos de espacios dentro de la esfera personal por los que las autoras se inclinaron, sus características y, sobre todo, las relaciones que establecieron sus protagonistas en ellos. Considero que avanzar en el análisis a estas representaciones literarias puede ayudarnos a comprender cómo las autoras percibieron su instalación en las esferas letradas.

Es precisamente esta tarea la que me propongo desarrollar en las páginas siguientes, y para esto me centraré en una selección de escenas, de distintas obras de un conjunto de narradoras latinoamericanas y caribeñas, que recogen representaciones de actividades culturales desarrolladas por sus protagonistas. Es necesario señalar que si bien estas actividades son variadas, prima en ellas un carácter letrado. En la mayoría de las narraciones estudiadas existe un evidente predominio de imágenes de lectura y escritura, siendo entre ambas la práctica lectora, individual o colectiva, la que más se reitera en las ficciones al momento de visibilizar la vida cultural de sus personajes. Esta razón, más el hecho de que estamos en un contexto de producción en donde la creación y circulación simbólicas se manifiestan hegemónicamente mediante la escritura (Rama), me llevan a definir estos espacios en principio como ámbitos principalmente letrados.

Por último, las escenas escogidas para este estudio corresponden a obras escritas en la primera mitad del siglo XX, cuyas autoras son las chilenas Marta Brunet y María Flora Yáñez, la venezolana Teresa de la Parra, la mexicana María Enriqueta, la dominicana Carmen Natalia y la cubana Dulce María Loynaz.

\section{Ceremonias letradas}

Joëlle Mertès-Gleize, en su estudio de la novela francesa del siglo XIX, señala que en la segunda mitad de esa centuria las escenas de lectura en la literatura experimentaron cambios en sus modos de representación. Si previo a este periodo los episodios en los que tenían lugar actividades lectoras aparecían como cuadros de carácter costumbrista, despojados de significación, actos que no llegaban a constituir imágenes de un mundo cultural, en la etapa histórica que le interesa a Mertès-Gleize la lectura tendrá una mayor incidencia simbólica y narrativa en la trama de las obras. La causa de este cambio, según Mertès-Gleize, se puede encontrar en el aumento del número de lectores en la sociedad francesa de mediados del siglo XIX. La lectura se transformó en una práctica habitual y, al mismo tiempo, significativa para el desarrollo de los sujetos. Su importancia social y cultural se vio, entonces, expresada en el valor que alcanzó la representación de la misma en la narrativa.

Siguiendo esta reflexión, debo agregar que la lectura, al constituirse en una experiencia compartida por grupos más amplios, tuvo alcances distintos a los que tenía cuando era una praxis restringida a ciertos círculos. En la medida que crecía la cantidad de lectores, tanto la escritura como la lectura dejaron de tener solo funciones de conservación y transmisión de conocimientos. En efecto, a mayor número de individuos alfabetizados, menor fue la capacidad del grupo social de controlar y orientar la experiencia 
lectora 6 . En este plano, la lectura posibilitó a los sujetos no solo enriquecer su capital cultural, informarse, adquirir pautas sociales, sino también permitió brindar momentos de distracción, desarrollar una reflexión crítica autónoma y explorar emociones y vivencias que muchas veces contravenían los parámetros morales burgueses7. Así, la lectura pasó de ser un medio a partir del que se mantenía una tradición a una experiencia que impulsaba la definición de una subjetividad nueva, capaz de tensionar y romper pautas de comportamientos, dando a su vez lugar a nuevas formas de percibir y entender el mundo, en definitiva una subjetividad moderna ${ }^{8}$.

Considerando las reflexiones de Raymond Williams en relación con el vínculo entre experiencia personal y transformaciones ideológicas y culturales, es posible sostener que esta nueva forma de entender y vivir la lectura se presenta como una estructura de sentir característica de una sociedad moderna. La lectura así percibida y sentida tendrá impacto en las imágenes literarias de la subjetividad y la sociabilidad burguesa. Es precisamente ese impacto el que identifica Joëlle Mertès-Gleize al advertir el cambio en los modos de ficcionalizar la praxis lectora.

El estudio de Mertès-Gleize abre una puerta de reflexión interesante al observar cómo las representaciones de las actividades artísticas y letradas experimentan cambios cuando ingresan nuevos agentes a los campos culturales y son otros los que empiezan a desarrollar dichas actividades. Teniendo en cuenta esto, amerita interrogarse qué pasa cuando esta otredad arraiga en una subalternidad de género sexual. En el caso de las autoras que interesan a este estudio, es importante destacar que ellas se inscriben en un contexto político y cultural en el que los márgenes de la ciudad letrada se han modificado producto del ingreso de nuevos sectores sociales a los espacios de producción y circulación simbólicas (Rama 158). Las mujeres, figuras relevantes de esta paulatina democratización de los espacios públicos, intelectuales y creativos, dejarán su impronta en la producción letrada no

6 De acuerdo con Terry Eagleton, a medida que aumenta la población alfabetizada, y su protagonismo en los espacios públicos europeos, surge en los sectores culturales más tradicionales una creciente preocupación por una clara "descomposición de la esfera pública". En estos nuevos lectores, que leen de todo, desordenadamente, sin orientación alguna, y con escaso discernimiento (de acuerdo con los patrones valóricos de los grupos hegemónicos), se gestaba una amenaza para la estabilidad social. Leer no significaba saber leer o, en otras palabra, leer correctamente (59).

7 Karin Littau señala que con el aumento de lectores en la modernidad, y la irrupción de la novela que se refería a mundos reconocibles por el público común, surgió el temor en ciertos grupos ilustrados de que los lectores se dejaran llevar pos sus emociones y perdieran todo sentido de realidad, olvidando con ello sus responsabilidades. Objeto de especial preocupación fueron las lectoras, las que por su "naturaleza" eran consideradas como seres fácilmente impresionables, corriendo el riesgo de ser más vulnerables a la imaginación literaria: "Se temía que ese exceso de identificación las arrastrara [...] a reproducir ideas extravagantes que hallaban en la lectura o, al menos, a obrar conforme a ellas" (45).

8 Michele Petit, al analizar la relación entre el ejercicio lector y la definición de una individualidad en términos modernos, plantea que la práctica lectora contribuye a "crear un espacio" (7), en el que el sujeto no solo puede perfilar otra "representación de sí mismo" (8), sino que también constituir un área de emancipación que dará lugar a un "yo" que pueda enfrentar la esfera pública y posicionarse en ella. Para Petit la lectura se despliega como un ámbito de formación imprescindible, sin ella no podría existir un sujeto autónomo. 
solo en términos cuantitativos, sino también instalando temas, reflexiones e imaginarios en el debate político y en la escena artística.

En relación con esto último, un rasgo característico de la representación de la experiencia cultural en la narrativa de las autoras es el valor que adquiere el retiro individual para la apreciación y manifestación simbólicas. Las autoras hacen depender la experimentación plena de la cultura por parte de las protagonistas, de la existencia previa de un cronotopo aislado del conjunto social. La actividad cultural entendida como instancia de refugio se escenificará en la literatura de mujeres de dos modos, o bien como cronotopo compartido con otros sujetos con intereses afines, o como espacio exclusivamente personal.

En la novela de María Flora Yáñez, Las cenizas (1949), encontramos estas dos formas de vivir las prácticas lectoras. En el relato, la protagonista, Irene, "Durante días enteros se separa del grupo para crearse una isla solitaria" (37). En esos momentos de aislamiento, ella se dedica principalmente a leer. Luego, se reúne periódicamente con un grupo reducido de amigos, en un lugar apartado del mundo escolar y de la hacienda familiar, para compartir textos en voz alta. Quien dirige la reunión es Hugo, un joven de aspecto frágil, culto e imaginativo. En un ambiente bucólico, Hugo es el encargado de leer los textos a los demás. El grupo termina configurando un cronotopo propio, organizado exclusivamente en función del ritmo narrativo que impone la voz del adolescente: "la grave voz de Hugo narra, narra siempre..." (38).

En la novela de Brunet, María Nadie (1957), volvemos a observar un encuentro de similares características. En el relato, una joven telefonista, María López, que se ha trasladado a ejercer sus labores a la provincia, descubre un espacio en medio de la naturaleza en donde puede apartarse de las desconfianzas que despierta su persona en el poblado. El lugar, de difícil acceso, con una única entrada por una grieta en las montañas, se constituirá en el refugio que la joven compartirá con dos niños, los que por casualidad encuentran ese portal natural. A diferencia de la novela de María Flora Yáñez, los personajes de María Nadie no leen sino más bien escenifican, recitan o cantan las historias que han sido parte de su formación lectora. Asumiendo roles de princesas cautivas, caballeros, piratas o actuando pasajes de Tom Sawyer y de novelas históricas, el mundo que configuran los personajes es un registro performático de sus propias lecturas (696-697). En María Nadie, la protagonista también buscará la soledad. Se la describe deambulando por el campo o recluida en su casa, intentando encontrar la desconexión necesaria para leer o simplemente disfrutar el silencio: "Arribaba ella, María López, a una de estas tantas casas e inmediatamente creaba su ambiente: un rincón para su cama, para su ropa, para sus libros. Un rincón, el más propicio al silencio, para leer y soñar" (730).

Tanto en Las cenizas, como en María Nadie, la soledad se construye, se crea o se busca, no es una condición, sino una opción. Lo es también en Ifigenia (1924), de Teresa de la Parra. En la novela de la escritora venezolana, María Eugenia encuentra en la habitación privada, en un lugar perdido en medio de la naturaleza o en un punto ciego en el cuarto de lavado, sus personales refugios letrados. Tendida en la cama, en la hierba o en medio 
de las ropas que esperan el planchado, la joven lee de todo. La protagonista encontrará, además, en la compañía de su amiga Cristina, esa instancia de comunión letrada en la que puede compartir intereses literarios y artísticos. Con Cristina generará una complicidad basada principalmente en la admiración intelectual y en gustos literarios afines: "Como sabes Cristina, siempre he tenido bastante afición a las novelas. También la tienes tú, y creo ahora que fue sin duda ninguna esta comunidad de gusto por el teatro y las novelas la que hizo que intimáramos tanto [... $]^{\prime \prime}(10)$. Las dos amigas trasladarán esta "comunidad de gusto", sostenida en confesiones personales, pasiones literarias y teatrales, a rincones apartados del internado o al mismo seno de la masa citadina, por donde deambularán ocultas en el anonimato, conversando acerca de la cartelera artística.

En las tres novelas mencionadas, la experiencia cultural se vive como un refugio frente a una sociedad que no comprende las inquietudes artísticas y críticas de las sujetos y que, en más de una ocasión, se torna amenazante para ellas. En Las cenizas los amigos dan por establecido que solo ellos pueden participar del cónclave que han creado. No existe la más mínima intención de abrir ese espacio a nuevos integrantes. Los otros: hermanos, familiares, profesores son para la protagonista seres "insignificantes" y "repulsivos" (35). La misma ambientación que rodea al grupo reafirma el carácter cerrado del mismo, un círculo de plantas, aves, animales de distinto tipo interactúan con los adolescentes y se despliegan, a su vez, como una barrera natural que los separa de las preocupaciones sociales y la rutina doméstica que priman en la vida hacendal y escolar.

En María Nadie ninguno de los tres protagonistas se refiere en sus encuentros al mundo exterior. Los niños desconocen todo respecto de la telefonista, no saben su nombre real, ni dónde vive, ni en qué trabaja. Ella, a su vez, ignora quiénes son sus pequeños acompañantes. Nunca hay preguntas, ni la más pasajera curiosidad por saber algo más de la vida de los otros, como si entendieran que el milagro de ese mundo que han creado solo se puede sostener a condición de dejar fuera sus otras vidas. En este particular escenario, el grupo construye una comunidad fuera del tiempo real. $\mathrm{Si}$ al otro lado de este cronotopo los tres personajes son víctimas de las enfermedades, los prejuicios, la ignorancia y la rutina, en el seno de esa comunidad alternativa todos tienen una nueva oportunidad de habitar otras identidades. En Ifigenia las reuniones de María Eugenia con su amiga Cristina, también tienen este carácter oculto. Sus encuentros aparecen para el resto como inocentes actividades del recreo escolar o reuniones para merendar entre clase y clase, pero ellas saben que su fin es otro y que el resto no puede estar en conocimiento de sus conversaciones, por más pueriles que estas sean. En las narraciones estudiadas el quehacer letrado en principio no se presenta como una actividad prohibida, sin embargo, la posibilidad de una sanción moral o de la incomprensión del entorno se percibe como una amenaza constante. En Ifigenia, la protagonista es cuestionada por su familia apenas se revela que ella pasa largas horas leyendo en el campo. Para acceder a libros evitando futuros cuestionamientos, María Eugenia armará un cuidadoso tráfico de textos con ayuda de la empleada de la casa, que logrará trasladar los libros bajo sus faldas desde la biblioteca hasta las manos de la joven. 
En definitiva, los encuentros en pequeñas cofradías o las actividades culturales de carácter individual tienen en estas obras un carácter clandestino. Se esconde lo que no se puede o no se desea visibilizar. La experiencia cultural en estas obras se percibe, entonces, como un momento que estimula formas de pertenecer y construir comunidad no admitidas por las convenciones sociales, así como también definiciones alternativas de la individualidad. En este marco, no es precisamente "otro yo" u "otros yoes" los que surgen en estos lugares protegidos, sino las verdaderas individualidades. Son los sentimientos, creencias y visiones más honestas de sí mismas/os las que aparecen en medio de las lecturas y las representaciones artísticas. La experiencia cultural, vivenciada en tales términos, opera como un pasaje que permite un desprendimiento paulatino de las fórmulas sociales y las poses que deben asumir y aprender a escenificar en el cronotopo social.

En la novela Jirón de mundo (1919), de la mexicana María Enriqueta, se puede observar un ejemplo de esto último. En el relato, la asistencia de la protagonista con un grupo de amigos a una velada musical en un café carece de rasgos mundanos. Desde el viaje al evento, hasta el concierto mismo, los asistentes viven un proceso de reconstrucción de sus subjetividades y una particular simbiosis con el espacio natural que rodea al café. El lugar, situado en la ciudad, está en medio de un parque con un gran bosque, y antes de acceder a la arboleda los personajes deben transitar por un largo camino que los va alejando del ruido urbano. La avenida de acceso se constituye como un pasaje de iniciación, en el que los participantes van despojándose de todas aquellas cargas y ataduras que los limitan en su vida cotidiana. En el bosque, todos los paseantes se funden en la armonía de ruidos, texturas y colores que se abre en esa suerte de catedral natural. Las individualidades desaparecen casi por completo. En el episodio, el narrador no menciona los nombres de los personajes. Al llegar al Café, cada uno vuelve a retomar los rasgos que los definen, las identidades regresan pero esta vez con una nueva intensidad: el ritmo musical y visual del ambiente los invita a explorar sus "yoes" de otra manera. Es precisamente esta sensación de un yo recuperado desde la alteridad la que se explicita en el monólogo de uno de los asistentes al escuchar la música de piano en el café: "¿Adónde vamos? Nos decimos. ¿Cuál es nuestro fin? ¿Quién nos lleva? ¿El viento? ¿El huracán?... No tenemos ni tiempo ni calma para descubrirlo; ya lo veremos, ya lo sabremos... Y seguimos en carrera loca, hasta que, de pronto, el grito de un pájaro nos detiene" (133).

En las obras estudiadas las experiencias culturales de las protagonistas adquieren, así, características rituales. Cuando la actividad intelectual y artística se desarrolla de manera colectiva, los integrantes se comportan como si fueran parte de una ceremonia, que como tal requiere de ciertos acuerdos tácitos para constituirse y funcionar. Estos acuerdos se sostienen en el carácter secreto y cerrado del grupo, pero también en una interacción igualitaria entre sus integrantes. En el seno de esa comunidad letrada, los personajes suspenden sus diferencias sociales, de clase y género sexual. Esto no impide, sin embargo, que surjan figuras predominantes, nuevos liderazgos, aunque no basados en las jerarquías sociales del exterior. En estas comunidades culturales siempre hay un participante que debido a sus 
cualidades se eleva por sobre el resto como una suerte de guía, que dirige las lecturas, los juegos, las actividades del grupo.

Cuando la actividad cultural es desarrollada de manera individual por las protagonistas, encontramos nuevamente este carácter ceremonial, con la salvedad que la sujeto en vez de establecer vínculos con otras y otros, lo hace con su entorno, con la naturaleza que la rodea o con el espacio y la atmósfera de las habitaciones en las que se encuentra. En "Niú" la poeta se hace rodear de una ambientación que se despliega como una proyección de sí misma: el misterio y el exotismo de la joven se ve espejeada en cada uno de los rincones de su casa. En Ifigenia, María Eugenia Alonso modifica el decorado de su habitación para que parezca la escena parisina que se ha visto obligada a dejar, y que ella rememora como uno de los pocos cronotopos en los que pudo construir su identidad de manera autónoma. En estas experiencias letradas individuales, las heroínas actúan como seres iluminados, sensibles y capaces de llevar a cabo procesos de introspección y comprender situaciones y fenómenos complejos. En "Niú", por ejemplo, el narrador describe a la poeta como una suerte de divinidad, y el lugar en el que habita como un templo de características paganas.

Las ceremonias rituales, en general, cumplen una función de conservación y perpetuación del grupo social. Al fundarse en la repetición, tienen un rol estabilizador frente a los cambios que vivencia toda comunidad $y$, al mismo tiempo, posibilita su regeneración, fortaleciendo los lazos que unen a sus miembros. Richard Sennett, al analizar los ritos que llevaban a cabo las mujeres en la Grecia clásica, observa que en general estas ceremonias rituales también permitían adaptar el pasado al presente, brindando una instancia en la que se podían escenificar prácticas y sensibilidades que en el medio social no estaban admitidas. El rito, en tal sentido, también puede operar como un espacio liberador, que abre zonas heterodoxas de construcción personal y colectiva.

El ritual es una de las formas en que los oprimidos [...] pueden responder a las ofensas y al desprecio que sufren en la sociedad, y, más en general, los rituales pueden hacer soportables los sinsabores de la vida y de la muerte. El ritual constituye la forma social mediante la que los seres humanos tratan de enfrentarse al rechazo como agentes activos en lugar de como víctimas pasivas (86).

En las obras estudiadas, la ritualización de los actos letrados contribuye a la construcción y conservación de un grupo, sin embargo, como hemos visto, ese grupo no corresponde a una comunidad amplia, sino más bien a individuos que han elegido tomar distancia de ese otro mundo social y cultural, un mundo hostil que les ha sido impuesto. La ceremonia letrada se presenta, así, como un espacio de celebración y de afirmación de la diferencia.

Joëlle Mertès-Gleize identifica en las imágenes de lectura de las obras que estudia, especialmente en la novela Graziella (1852) de Lamartine, este mismo carácter ceremonial. En esa novela, el episodio en donde el joven aristócrata europeo lee a un grupo de pescadores analfabetos, aparece como 
un evento de rasgos litúrgicos: "El libro habla por la boca del que lo lee, el oficiante de esta ceremonia primitiva" (112). Para Mertès-Gleize la naturaleza habla por medio del libro, y el joven letrado es el elegido para traducir ese mensaje natural. Aparte del muchacho ilustrado, nadie habla en esta escena. Es un auditorio silencioso y, a la vez, totalmente cautivado por las palabras del ceremoniante. Mertès-Gleize ve en este tipo de escena, de la narrativa decimonónica francesa, una suerte de resabio de una forma popular de experimentar la lectura que estaba en las prácticas lectoras colectivas previas al aumento de la alfabetización: "La lectura colectiva reencuentra así el impacto y la autenticidad que había perdido en su versión mundana. Suscita emociones y no reacciones verbales" (111-112).

A diferencia de los textos revisados por Mertès-Gleize, las representaciones lectoras y culturales de las obras estudiadas en este artículo recogen tanto estas formas residuales de vivenciar los procesos simbólicos como también imágenes que remiten a modos modernos de entender la lectura y el arte. En efecto, en los episodios en los que se exponen maneras colectivas de compartir la lectura y la cultura en general, es posible observar rasgos similares a los que advierte Mertès-Gleize en Graziella: una performance ceremonial en la que por momentos la individualidad de sus integrantes se suspende para dar paso a una comunidad que es guiada por la voz y las decisiones de una figura principal, suerte de "sacerdote" o "sacerdotisa" que se presenta como un/a traductor/a de signos y designios que lo/a trascienden ${ }^{9}$. Sin embargo, sería inexacto definir estas ceremonias letradas como cronotopos en los que el sujeto y sus capacidades intelectuales y artísticas se anulan completamente en función del colectivo. Por el contrario, estas ritualizaciones culturales se completan solo cuando sus integrantes, sobre todo los personajes femeninos, pueden resignificar y reasumir sus individuales. En estas comunidades culturales tiene lugar el enriquecimiento y fortalecimiento del "yo" y no su disolución en el grupo. En Ifigenia la preadolescente, María Eugenia, recuperará parte de su personalidad emancipada e inquieta intelectualmente que tenía en su infancia en el mundo rural, con los encuentros con su amiga Cristina. En Las cenizas, la protagonista descubrirá en el pequeño grupo que rodea a Hugo, un lugar que impulsa esa autenticidad individual que su mundo familiar y social obstaculiza. En María Nadie, las reuniones secretas entre los niños y la joven se presentan como espacios de revitalización personal. En esta novela de Brunet, la interrupción de los encuentros y la sospecha de que María López reveló a alguien más la existencia de la comunidad secreta, dará lugar no solo a una crisis de confianza, sino también a todas las amenazas que debilitan la autonomía de los personajes: la enfermedad y los prejuicios.

\footnotetext{
9 Karin Littau señalará que en la Edad Media, previo a la imprenta y a la elaboración masiva de libros, la producción letrada estaba a cargo de copistas que reproducían los textos, los que en el ejercicio de registrar se permitían también modificar partes de los manuscritos originales. En aquel entonces, señala Littau, no habían mecanismos para distinguir entre e autor y el reproductor, entre el poeta y el que recita (40). Para la percepción premoderna, por tanto, nada era fruto de la conciencia y la creatividad individual, sino parte de una corriente significante sin autoría, que era comunicada por el poeta, quien operaba como un canal que daba a conocer la "inspiración divina" (40).
} 
Esta afirmación del yo se expresa con más claridad en aquellos pasajes en donde las sujetos experimentan de manera totalmente individual los procesos de producción y recepción cultural. En la novela de la dominicana Carmen Natalia, La victoria $(1950)^{10}$, se presenta un prólogo de una autora ficcional, llamada Renee Millet. En ese apartado la aspirante a escritora revela las dudas e incertidumbres creativas que enfrenta al tener que escribir una novela. El relato de Carmen Natalia es uno de los pocos en donde se observa una férrea determinación por parte de una protagonista de convertirse en una escritora profesional. Sin embargo, para ella este objetivo no pasa por integrarse y participar en los campos culturales, sino por alejarse de la ciudad, de sus influencias y desarrollar en el mundo rural su trabajo creativo. El aislamiento le permitirá volver a creer en sus capacidades, ser como ella señala "dueña de mí misma" (4). En la novela Jardín (1935)11, de Dulce María Loynaz, volvemos a observar este vínculo entre definición de sujeto y constitución de un espacio cultural personal. La protagonista, Bárbara, al rememorar su infancia, concede especial importancia a sus momentos de lectura en la casa familiar rodeada por un jardín que la aísla del exterior. Sentada en el enorme sillón de la biblioteca, la pequeña se sumerge en las páginas de los libros que dan lugar a verdaderas máquinas de ficcionalización. En la novela de Loynaz, la interrupción de la lectura no solo significa el fin de una instancia creativa y liberadora, sino también el inicio de la crisis de la sujeto: "Y sobrevino un adormecimiento suave, un lento olvido de sí misma, una muerte sorbida en dosis infinitesimales. Desde ese momento, Bárbara vivió sin vivir" (78).

En prácticamente todas las novelas analizadas la posibilidad de la autodeterminación femenina está asociada a la existencia de estas esferas culturales, colectivas o individuales en las que las sujetos leen, reflexionan y desarrollan procesos creativos con relativa libertad. Así, las autoras hacen coincidir en sus obras experiencias culturales de carácter premoderno, en donde las sujetos entran en comunión con los integrantes y el entorno, desdibujando sus límites, con procesos que apuntan a la autoafirmación de la individualidad. En este marco, es lógico preguntarse por qué las experiencias culturales en estas novelas combinan estructuras de sentimiento de carácter residual con formas de percibir y entender la cultura asociadas a la modernidad. A mi modo de ver, la razón está en la forma en que ellas vivieron y entendieron los procesos modernos. Si atendemos a los escritos ensayísticos de autoras como Teresa de la Parra o Gabriela Mistral, acerca de la "nueva mujer" y su participación en las esferas públicas ${ }^{12}$, observaremos un desplazamiento de posiciones que va desde el entusiasmo a la cautela. Entusiasmo, porque la modernidad se presenta como una oportunidad histórica para que el sujeto femenino pueda alcanzar mayores y mejores posibilidades de autodesarrollo; y cautela, porque esa misma modernidad opera con ciertas restricciones, conservando y renovando bajo nuevos lenguajes varios prejuicios respecto de la mujer y a otros sectores sociales; prejuicios anclados en una racionalidad

10 Fue escrita entre 1945 y 1950 . Se publicará por primera vez, póstumamente, en 1992. 11 Fue escrita entre 1928 y 1935. Se publicará recién en España en 1955.

12 Al respecto, ver Teresa de la Parra, "Tres Conferencias. Influencia de las mujeres en la formación del alma americana", en Obras, Caracas, Biblioteca Ayacucho, 1982. Gabriela Mistral "Introducción", en Lectura para mujeres, Ciudad de México, Escuela Hogar, 1924. 
excluyente que desvalorizaba y marginaba el cuerpo y los afectos, y que condenaba, e incluso patologizaba, lenguajes, prácticas y formas de comportamiento que no se adecuaban al proyecto burgués. Debido a esto, muchas escritoras optaron por conservar, junto con los lineamientos más liberadores de la modernidad, ciertos modelos de vida o visiones que se asociaban a epistemes o prácticas premodernas ${ }^{13}$. El rescate del misticismo en los discursos de Teresa de la Parra, de los lazos domésticos y las prácticas sagradas en las reflexiones de Gabriela Mistral, no obedecen a una "íntima tristeza reaccionaria" -como señaló Ramón López Velarde en relación con la novela Las memorias de mamá Blanca, de Teresa de la Parra-, sino a una necesidad de retener en el presente moderno aquellos valores que le permitían constituir una comunidad basada en los afectos.

No es extraño, por tanto, que estas ceremonias letradas no estuvieran exentas de atmósferas que contravenían el proyecto burgués ilustrado. Al respecto, la naturaleza se despliega como un entorno recurrente en el que las protagonistas constituyen sus actos culturales en oposición a la urbe. Este es el caso de Ifigenia, donde María Eugenia lee y escribe en medio de un paisaje natural que parece solo dispuesto para ella, para su relajo y su desconexión del mundo familiar y urbano: "Y sobre la piedra del río, con el libro por cartera, y mis rodillas por escritorio, limando de tiempo en tiempo en una peña vecina la punta de mi lápiz cuando se hacía muy roma, mientras duró la luz del día estuve escribiendo" (143-144). En estos relatos la naturaleza ofrece lo que la ciudad no entrega: los estímulos para la creatividad y el refugio necesario para que la sujeto pueda leer y desarrollar su propia escritura. La naturaleza posibilita que las sujetos sean fieles a sí mismas, presentándose como un entorno que las estimula a mostrar una suerte de verdad profunda, que la ciudad tiende a invisibilizar. Así, mientras la ciudad y los mundos sociales, en general, se revelan como espacios artificiales, en los que se privilegia la impostura corporal, la pose y el lenguaje ensayado, en el espacio campestre las protagonistas se reencuentran con un estado primigenio, libre de las codificaciones aprendidas ${ }^{14}$. Como señala el personaje Renee Millet en La victoria: "Había un silencio acogedor en aquel pedacito de mundo tan lejos de la ciudad" (4). La joven encuentra que es la naturaleza provinciana el lugar preciso para iniciar su primera novela:

Tendí mi chaqueta sobre la hierbecilla húmeda de rocío que había nacido como un amanecer de esperanzas sobre un recio peñón y me acomodé lo mejor que pude disponiéndome a trabajar en seguida. Mi pluma inició algunas

\footnotetext{
13 Es este rasgo el que advierte Sylvia Molloy en las obras de las escritoras de ese periodo, a partir del análisis a la narrativa de Teresa de la Parra. "La premodernidad programática que defienden desde su exilio -mediante esos 'otros' diferentes que los proyectos estatales hispanoamericanos descartan hacia los márgenes, los negros de Parra y Cabrera, los campesinos, los indios de Gabriela Mistral- se inscribe en contra de una modernidad cuya taxonomía genérica y sexual no las incluye" (286).

14 Carmen Rosa Ringeling analiza la importancia que tiene la naturaleza en la definición de la subjetividad en las novelas de Marta Brunet y María Flora Yáñez. La investigadora planteará que en "[...] la naturaleza es concebida como un estadio primigenio, pero 'primigenio' entendido como originario, esencial, incluso verdadero; frente a la cultura que se concibe como lo artificial, lo codificado, lo convencional, lo restrictivo, llegando incluso a ser lo falso" (27).
} 
líneas imprecisas. Mi imaginación daba vueltas como un corcel sin freno $(4-5)$.

En las novelas, estos espacios de creación y circulación cultural funcionan también como entornos que posibilitan a las y los sujetos conectarse de manera más profunda y libre con sus propios cuerpos. En este marco, leer o escribir no es solo un ejercicio de carácter intelectual y creativo, sino también una experiencia erótica, en la que los deseos sexuales tienen un canal de expresión sin ser condenados. En Las cenizas se describe así el conjunto de sensaciones que tiene el personaje femenino cuando escucha la lectura literaria de Hugo: "Irene siente que puede pasar un tiempo indefinido, tal vez toda la vida, así tendida al sol, mientras saborea la roja carne de la fresa" (37). Asimismo, en María Nadie, si bien la relación entre la joven y los niños está sostenida en un artificio romántico de cuentos de hadas, este vínculo no es plenamente inocente y retórico. El enamoramiento de los niños es real, la atracción física que sienten por la joven es uno de los factores que motiva e impulsa los encuentros secretos.

Susana Zanetti repara precisamente en esta conexión entre lectura y erotismo en la novela Ifigenia. De acuerdo con Zanetti, la narración de Teresa de la Parra presta especial atención a describir el contacto del cuerpo de la joven con las texturas del entorno mientras lee. "La lectura a solas impregna esa escritura de la intimidad, de la confidencia, así como palpita en los devaneos con el cuerpo, susurrados por la imaginería novelera" (320). En Ifigenia la suavidad de las sedas, la vegetación, el fluir del agua envuelven el cuerpo de la adolescente, llevando su experiencia lectora a una placentera excitación física.

En definitiva, en las novelas analizadas se observa la configuración de representaciones culturales en espacios ajenos al devenir público moderno, representaciones en las que se despliegan acciones letradas de rasgos ceremoniales (individuales o colectivas) en las que las autoras problematizan el carácter excluyente de sus campos culturales. Las escritoras, como señala Masiello, escogieron replegar a sus protagonistas a ámbitos personales y privados para evidenciar, así, los procesos de marginación y deslegitimación que vivenciaron en sus respectivos espacios artísticos e intelectuales. Las ceremonias letradas se presentan en las ficciones como esferas alternativas a esa sociabilidad burguesa que se expresa en la familia, la escuela y las esferas públicas. En estas ceremonias, los sujetos, especialmente los personajes femeninos, viven las actividades simbólicas como instancias de definición individual, que les permiten reafirmar su yo y, al mismo tiempo, entrar en comunión con otras y otros.

\section{Obras citadas}

Bourdieu, Pierre. Las reglas del arte. Génesis y estructura del campo literario. Barcelona: Anagrama, 2011.

Brunet, Marta. María Nadie en Obra narrativa. Novelas. Tomo I. Edición crítica a cargo de Natalia Cisterna, Santiago de Chile: Zig-Zag, 2014. . "Niú", en Reloj de sol en Obras Completas. Santiago: Zig-Zag, 1963. 
Carmen Natalia. La victoria. Santo Domingo: Centro de solidaridad para desarrollo de la mujer (CE-Mujer), 1992.

Carreño, Rubí. "Una escena crítica: estereotipos e ideologías de género en la recepción crítica de Marta Brunet y María Luisa Bombal". Anales de Literatura Chilena, 3 (2002): 43-51.

De la Parra, Teresa. "Tres Conferencias. Influencia de las mujeres en la formación del alma americana", en Obras. Caracas: Biblioteca Ayacucho, 1982.

"Carta a Eduardo Guzmán Esponda" [1926]. En OOCC. Caracas: Editorial Arte, 1965.

Ifigenia. Diario de una señorita que escribió porque se fastidiaba. Lima: Ediciones Antártica, 1960.

Doll, Darcie. "Escritoras chilenas de la primera mitad del siglo XX: trayectoria en el campo literario y cultural como criterios para una periodización de su producción". Taller de Letras, 54 (2014): 23-38.

Eagleton, Terry. La función de la crítica. Barcelona: Paidós, 1999.

Fletcher, Lea. "La profesionalización de la escritora y de sus protagonistas. Argentina, 1900-1919". Revista Iberoamericana, 206 (2004): 213-224.

Loynaz, Dulce María. Jardín. La Habana: Editorial Letras Cubanas, 1993.

María Enriqueta. Jirón de mundo. Madrid: Editorial América, 1919.

Masiello, Francine. "Texto, ley, transgresión: especulación sobre la novela (feminista) de vanguardia". Revista Iberoamericana, 132-133 (1985): 807-822.

Mertès-Gleize, Joëlle. "Lectures Romenesques", en Romantisme, 47 (1985): 107-118 (La traducción de este artículo fue realizada por Lucía Stecher).

Mistral, Gabriela. "Introducción", en Lectura para mujeres. Ciudad de México: Escuela Hogar, 1924.

Molloy, Sylvia. "Secreto a voces: traslados lésbicos en Teresa de la Parra", en Poses de fin de siglo. Desbordes del género en la modernidad. Buenos Aires: Eterna Cadencia Editora, 2012.

Rama, Ángel. Rubén Darío y el modernismo. Barcelona: Alfadil Ediciones, 1985. La ciudad letrada. Santiago de Chile: Tajamar Ediciones, 2004.

Ringeling, Carmen Rosa. La urgencia de lo íntimo: Las cenizas de María Flora Yáñez y María Nadie de Marta Brunet. Tesis de Magíster en Literatura. Santiago de Chile: Universidad de Chile, 2014.

Sennett, Richard. "El manto de las tinieblas. La protección de los rituales en Atenas", en Carne y piedra. El cuerpo y la ciudad en la civilización occidental. Madrid: Alianza Editorial, 1997.

Williams, Raymond. Marxismo y literatura. Barcelona: Ediciones Península, 2000.

Zanetti, Susana. "La escuela de las esposas: Ifigenia de Teresa de la Parra", en La dorada garra de la lectura. Lectoras y lectores de novela en América Latina. Rosario, Argentina: Beatriz Viterbo Editora: 2010. 